\title{
Special Issue \\ Constitutional Identity in the Age of Global Migration
}

\section{Constitutional Identity in the EU-A Shield or a Sword?}

\author{
By Pietro Faraguna*
}

\begin{abstract}
This Article consists of five sections. In the first section, it describes why identity questions matter, particularly in Europe. In the second section, the Article tackles the issue of multiple structural ambiguities affecting the concept of constitutional identity in the European constitutional vocabulary. In the third section, the Article explores trends concerning the use of constitutional identity in the European legal discourse and practice, including the development of alternative interpretations and applications of the notion of constitutional identities in the Member States. The fourth section of the Article combines the analytical accounts outlined in the second section with the trends identified in the third section, contending that different conceptions and applications of constitutional identity have varying effects on the European composite constitutional adjudication system and that the institutional and procedural framework should be calibrated accordingly. The final section of this Article draws some conclusions.
\end{abstract}

\footnotetext{
* An earlier version of this article was presented at the workshop on "Constitutional Identity in the Age of Global Immigration: Theoretical and Comparative Perspectives," held in at the WZB Berlin Social Science Center on June 30 and July 1, 2017. I would like to thank the conveners, Jürgen Bast, Mattias Kumm, and Liav Orgad for giving me the opportunity to discuss my draft paper with an extremely qualified and inspiring group of scholars and for their insightful comments. I would like to thank the workshop's participants for the fruitful debate that gave a terrific contribution in improving my article. In particular, I would like to thank Jelena von Achenbach, Matej Avbelj, Matteo Daicampi, Nicola Lupo, Cesare Pinelli, Oreste Pollicino, and Giovanni Zaccaroni who read an earlier version of the present article and provided precious comments. Here as everywhere, the usual disclaimer applies: nobody but the author can be taken to account for omissions and imperfections that remain.
} 


\section{A. Constitutional Identity in the European Union: The Epicenter of a Global Debate}

In recent years, questions about the identity of the constitutional subject took center stage among public lawyers. ${ }^{1}$ Decisions over who may or may not be included in the "we" became increasingly crucial in an ever more globalized and interconnected world. Post-national, post-sovereign, constitutional patriotic, and many other alternatives have been theorized to offer new foundational justifications to the question of identity. Rather than a national terminology, identity has been increasingly phrased through the constitutional. Global immigration certainly played a crucial role in raising new challenges on the "membership" issue. Furthermore, the question of identity-however shaped-is far from being settled. States are increasingly challenged as their borders are compromised by humanitarian crises and mass, irresistible flaws of unauthorized migration. ${ }^{2}$

These questions emerged in a particularly dramatic manner in Europe. This specificity is unsurprising for several reasons. Europe is a small continent, bearing a unique intensity of difference and contrast. ${ }^{3}$ Compared with the rest of the world, part of Europe's character is the richness brought by the many different languages spoken as well as histories and traditions in an area of only half a million square kilometers, characterized by a high level of legal-and specifically, constitutional-integration. Diversity is not only an empirical evidence, but a normative premise of the integration process that follows the European motto of "United in Diversity."

Against such a background of differences and contrasts, it is not a coincidence if Europe experienced a rise of identity claims over the last two decades. Only 20 years ago, the last remaining multi-ethnic states in Europe or at its close borders collapsed and made room for more nationally homogeneous entities. The 1990 s were ripe with multiple claims to national identity: The term "identity" made it very quickly into the European public law vocabulary, partly substituting for the old-fashioned, down-graded and scary vocabulary of sovereignty. ${ }^{5}$

${ }^{1}$ Recently, a significant increase in the case-law on the identity-clause was accompanied by an impressive burst in the literature on the topic. For books entirely dedicated to the topic, see ELKE CLOOTS, NATIONAL IDENTITY IN EU LAW (2015); Francois Xavier Millet, L'Union Europeenne et l'identite constitutionnelle des Etats membres (2013); Alejandro Saiz Arnaiz \& Carina Alcoberro Llivinia, National Constitutional Identity and European InTEgration (2013); L'IDENTITE CONSTITUTIONNELLE SAISIE PAR LES JUGES EN EUROPE (Laurence Burgorgue-Larsen ed., 2011). From the German speaking literature, see Schwerpunkthema, in SUSANNE BAER ET AL., JAHRBUCH DES ÖFFENTLICHEN RECHTS DER GEGENWART (2015).

2 See Seyla Benhabib, The Rights of Others: Aliens, Residents, and Citizens (2004).

${ }^{3}$ These considerations open the formidable history of postwar Europe. See TONY JUDT, POSTWAR: A HISTORY OF EUROPE SINCE 1945 (2006).

${ }^{4}$ On the Motto of the EU, see Gabriel N. Toggenburg, Unity in Diversity: Searching for the Regional Dimension in the Context of a Someway Foggy Constitutional Credo, in AN EVER MORE COMPLEX UNION 27-56 (2004).

${ }^{5}$ More than ten years ago, it was noted that "to protect national sovereignty is passé; to protect national identity by insisting on constitutional specificity is à la mode." J. H. H. Weiler, A Constitution for Europe? Some Hard Choices, 
Not by chance the obligation to respect the national identities of the Member States was included for the first time in the 1992 Maastricht Treaty. ${ }^{6}$ The Maastricht Treaty introduced the first version of the national identity-clause as one of the tools enacted at European level to tackle national constitutional concerns ${ }^{7}$. The idea of the protection of national traditions and national diversities was not new, and characterized the European integration process from its onset.

After the introduction of the Treaty of Maastricht, however, legal tools, mechanisms and techniques serving this objective have been refined and enriched. In fact, the Maastricht Treaty represented a "constitutional moment" in the EU. Many novelties introduced by the Maastricht Treaty could challenge the role traditionally played by Member States since the establishment of the Westphalian model of international relations. Among these novelties, challenges emerged particularly from the introduction of a European citizenship, the establishment deeper economic and a monetary Union, and the commitment towards an ever-closer political Union.

National fears of a supranational entity overcoming Member States were tempered by the introduction of principles aimed at safeguarding Member States. ${ }^{8}$ The introduction of the identity clause was part of this strategy. The national identity clause, first introduced in Article F of the Treaty on the European Union (EU), ${ }^{9}$ aimed at counterbalancing the emphasis

40 JCMS J. COMMON MKT. STUD. 563-80, 569 (2002). On the importance of the innovation in the European vocabulary, see Monica Claes, National Identity: Trump Card or Up for Negotation?, in NATIONAL ConstitUTIONAL IDENTITY AND EUROPEAN INTEGRATION 109, 110 et seq. (Alejandro Saiz Arnaiz \& Carina Alcoberro Llivinia eds., 2013). It is telling enough that Flaubert described the concept of constitutional identity in its "Dictionary of Received Id eas" (1911) as "national or nationalistic delirium, dogmatic caprice of law professors, identity card of nation states, modern variation of the idea of sovereignty." Laurence Burgorgue-Larsen, L'identité constitutionnelle en question, in L'IDENTITE CONSTITUTIONNELLE SAISIE PAR LES JUGES EN EUROPE 155, 155 (Laurence Burgorgue-Larsen ed., 2011).

${ }^{6}$ In 1992, a national identity clause was first inserted in the Treaty of Maastricht. Article F (1) TEU recognized such obligation by plainly stressing that "the Union shall respect the national identities of its Member States." Article F (1) TEU of the Maastricht Treaty was later replaced by Article 6 (3) TEU of the Amsterdam Treaty in 1997, which then gave way to Article 4 (2) TEU of the Lisbon Treaty in 2009, currently in force.

${ }^{7}$ According to some authors, the identity clause was introduced as a counterbalance of the principle of EU law primacy. See Armin von Bogdandy \& Stephan Schill, Overcoming Absolute Primacy: Respect for National Identity under the Lisbon Treaty, 48 COMMON Mкт. L. Rev. 1417-53 (2011); Theodore Konstadinides, Constitutional Identity as a Shield and as a Sword: The European Legal Order within the Framework of National Constitutional Settlement, 13 CAMBRIDGE YEARBOOK. EUR. LEG. STUd. 195, 198 (2012).

${ }^{8}$ On the role played by the identity-clause as a constitutional price paid to the objective of a further political, economic and constitutional integration within the EU, see Claes, supra note 5, at 118; CLOOTS, supra note 1, at 63, 82, 179, 184.

${ }^{9}$ The first provision in a European Treaty that explicitly mentioned national identity was Article F of the TEU (postMaastricht version): "the Union shall respect the national identities of its Member States, whose system of government are founded on the principles of democracy." 
put on common principles and supranational constitutionalization. ${ }^{10}$ This balancing and counterbalancing dynamics persisted in the successive amendments of the Treaties. The Treaty of Amsterdam reformulated Article F, and renumbered it as Article 6(3), splitting the recognition of the democratic principle as a founding principle of Member States government from the protection of national identities. In addition, and more significantly, the Treaty introduced the subsidiarity principle as a new possible legal tool to accommodate contrasting European and national claims. The most impacting reformulation of the identity clause, however, was introduced by the Treaty of Lisbon, which represented the last textual landmark in the evolution of the identity discourse. Article 4(2) was the first EU-Treaty provision to explicitly codify national constitutional identity. For the first time, the wording shifted from the purely national qualification of identity to a much wider one. National identity was then, and still is, inherent in Member States' "fundamental structures, political and constitutional, inclusive of regional and local self-government." ${ }^{11}$ Furthermore, the Charter of Fundamental Rights of the European Union (CFREU), that became legally binding with the entry into force of the Treaty of Lisbon in 2009, provided for the obligation to respect the "national identities of the Member States and the organization of their public authorities at national, regional and local levels."12

In brief, the Treaty of Lisbon gave a remarkable contribution for the enrichment of the legal-and more precisely, constitutional-meaning of the identity clause, by weakening sociological and historical reference of the clause. ${ }^{13}$ The Court of Justice of the European Union (ECJ) case law was concretely impacted by this shift of meaning of the clause. Whereas in the pre-Lisbon case law, the national identity clause enshrined in Article F and 6(3) TEU was a rarely used battleground, or meeting point, between the EU and the Member States before the ECJ, after the adoption of the Lisbon Treaty, Article 4(2) made it into the legal reasoning of the ECJ. For better or worse, the "constitutionalization" of national identity, textually occurred with a change of terminology in the Lisbon Treaty, ${ }^{14}$ made the identity-

\footnotetext{
${ }^{10}$ See Claes, supra note 5, at 118.

11 Article 4(2) of the Treaty of Lisbon Amending the Treaty on European Union and the Treaty Establishing the European Community art. 3a, Dec. 13, 2007, 2007 O.J. (C 306) 1.

${ }^{12}$ Charter of Fundamental Rights of the European Union preamble, 2010 O.J. (C 83) 2, at 391.

${ }^{13}$ The new wording of the identity clause "distances the notion of national identity in Article 4(2) TEU from cultural, historical or linguistic criteria and turns to the content of domestic constitutional orders." Cf. von Bogdandy \& Schill, supra note 7, at 1422.. For an account in the same sense, see Claes, supra note 5, at 116.

${ }^{14}$ The "constitutionalization" of the phrasing of the identity clause go back to the so-called Christophersen clause of the ill-fated Treaty establish a constitution for Europe, as elaborated by the working group $V$ of the Convention, chaired by Mr. Christophersen. For a detailed discussion of the genesis of Article 4(2) TEU, see Barbara Guastaferro, Beyond the Exceptionalism of Constitutional Conflicts: The Ordinary Functions of the Identity Clause, YEARBOOK EUR. L. 263-318 (2012).
} 
terminology ever more acceptable, ${ }^{15}$ if not attractive and superficially appealing. The "constitutionalization" of the EU concept of national identity with the Treaty of Lisbon was immediately seen as a possible transformation of the national identity clause into "the battleground or the meeting point, where the limits of the authority of EU law lie". ${ }^{16}$

Nevertheless, the identity-discourse seems to be turning the corner again. The refugee crisis-in front of which Europe is geographically particularly exposed-added new layers of contrasts and raised new challenges over a continent that was already under the pressure of one of the harshest economic crises of the last century. Political and sociological debates connected with national identities flourished: Le grand débat sur l'identité nationale, the Britshness debate that was closely connected with the Brexit debate aiming at "taking control back," the controversy on the existence of a Dutch national identity and the struggles of the Belgian contested national identity are not isolated manifestations of nostalgic feelings, but are revealing a new trend. National identity rhetoric praises the political statements of many leaders of Member States. ${ }^{17}$ Against such a background of new contrasts and challenges, the European "constitutional path" of identity seems to be subject to a new process of transformation. Nowadays, to protect national identity is à la mode not anymore only by insisting on constitutional identity, ${ }^{18}$ but also by adjudicating EU law on the basis of constitutional identity.

This Article explores this new trend, moving from the verification of constitutional identity as a new explicit battleground of disputes between the ECJ and national Constitutional and Supreme Courts. When constitutional identities are used as shields, they may play a role in guiding or blocking legal reform in the EU. On the contrary, when constitutional identities are used as swords, the role played is significantly different from the one played by constitutional identities as shields: constitutional identities used as swords are aimed at composing legal conflicts within the EU composite constitutional system. The Article claims that in this scenario, a greater role should be recognized to national players when constitutional identities "as difference" enter the conflict.

\footnotetext{
${ }^{15}$ See Mattias Kumm, The Jurisprudence of Constitutional Conflict: Constitutional Supremacy in Europe before and after the Constitutional Treaty, 11 EUR. L.J. 262-307 (2005).

${ }^{16}$ Damian Chalmers, Gareth Davies \& Giorgio Monti, European Union LaW: CASES AND Materials 202 (2010).

${ }^{17}$ For some meaningful examples, see CLoots, supra note 1 , at 1.

${ }^{18}$ Weiler, supra note 5 , at 569.
} 


\section{B. Ambiguities}

Even though studies regarding the concept of constitutional identity flourished in recent years - with a concentration in the European legal scholarship - "the legal concept remains largely indeterminate."19 This indeterminacy is partly due to a structural character of the concept and partly connected to multiple ambiguities of the identity-terminology. ${ }^{20}$ Moreover, a "constitutional understanding of constitutional identity" may legitimately decide to privilege some specific aspects and overlook others. Constitutional identity may be accessed through the investigation of the "identity of the people" or through the investigation of the "identity of the constitution;" constitutional identity may emerge "through the prism of citizenship" 21 or by mirroring a "societal culture." 22

In this Section, the Article tackles the issue of several structural ambiguities of the concept of "identity" in the European constitutional vocabulary. The exploration of the multiple ambiguities characterizing the concept aims at developing a theoretical map, where different conceptions of the same concept are clarified. The article claims that constitutional identity in the European legal debate may refer to the constitutional nature of the EU"European constitutional identity" - or to the constitutional identities of the Member States-"national constitutional identities". Additionally, in this section, a further ambiguity is explored by making a distinction between constitutional identity as a reference to those characters that make one constitution different from another constitution- "constitutional identity as difference" - and those characters that are not subject to modification, either by constitutional amendments or by interpretative transformations, and therefore, "eternally" characterize a given constitution-“constitutional identity despite difference."

\section{European versus National Constitutional Identity}

The construction of a constitutional narrative in the ECJ jurisprudence is a well-known story, but its remodeling in terms of construction of a European constitutional identity may prove illuminating of one layer of ambiguity affecting the concept, even if it can only be brief and schematic. In fact, among the many conceptions that may be drawn from the concept of constitutional identity, one of them is related to the possible identification of a legal order in constitutional terms. Following this conception, the constitutional identity of a certain

\footnotetext{
${ }^{19}$ CLOOTS, supra note 1 , at 174 .

${ }^{20}$ For a critique of the use of the term identity in many fields, see LUTZ NiETHAMmER, KollekTIVE IDENTITÄT. HeimLiCHE QUELLEN EINER UNHEIMLICHEN KONJUNKTUR (2000).

${ }^{21}$ Michel Rosenfeld, The Identity of the Constitutional Subject: Selfhood, Citizenship, Culture, and Community 243 (2009). This interpretation key to constitutional identity was recently undertaken by Liav Organd. See LIAV ORGAD, The Cultural Defense of Nations: A Liberal TheOry of Majority Rights (1st ed. 2016).
}

${ }^{22}$ Will Kymlicka, Multicultural Citizenship: A Liberal Theory of Minority Rights (1995). 
polity derives from the fact of having a constitution: "Polities with a constitution differ from those that do not." 23

Polities having a constitution in this descriptive sense should necessarily have some essential institutional architecture, with some form of formal vertical connection between layers of government. ${ }^{24}$ In the EU, even though a full-fledged federalism is not present, a settled architecture of institutional mechanism is working and is accepted and recognized by citizens, states, and institutions. The ECJ has long been defining the European Treaties as a "Constitutional Charter.".25

This said, formal infrastructures are not enough to design a viable EU constitutional order. A minimum level of material convergence is needed. What this minimum level precisely entails may be matter of discussion. It is probably much less of what is commonly assumed. Material divergences of full-fledged federal states confirm this impression: The US is certainly a federal state, even though its federalist structure allows states to regulate some crucial issues such as death penalty in radically different manners.

Material divergence, however, was perceived as a serious threat to the affirmation of a EU constitutional identity when some national constitutional courts started to put into doubt the principle of primacy of EU law. If EU law was to prevail over national law, including national constitutional law, it would become possible for EU law to infringe the fundamental rights standard protected by national constitutions. The evolution of the EU's fundamental rights guarantees-mainly triggered by the so-called judicial dialogue between the ECJ and national constitutional courts - is well-known story and has finally led to the adoption of the European Charter of Fundamental rights in 2009. Within this story, the ECJ has increasingly employed a "constitutional semantics." 26 The process of constitutionalization of the EU was not only characterized by the recognition of fundamental rights, but also by a process of progressive adherence to a sui generis conception of constitutional rigidity. The "intensification" of the European legal regime was accompanied by a generalization of its norms. This process factually made the general principles of this intense and "unorganized"

\footnotetext{
${ }^{23}$ Michel Rosenfeld, Constitutional Identity, in The Oxford HaNdBook of Comparative Constitutional LAW 756-76, 757 (2013).

${ }^{24}$ ROSENFELD, supra note 21 , at 249.

${ }^{25}$ Case 294/3, Les Verts, ECR 1986-4. See also Opinion 1/76, ECR 1977-I para 12; Case C-2/88, Zwartfeld, ECR 1990-

7 I; Case C-134/91, Beate Weber v. European Parliament, ECR 1993-I, p.1093, para 8.

${ }^{26}$ Armin von Bogdandy, Founding Principles of EU Law: A Theoretical and Doctrinal Sketch, 16 EUR. L.J. 95-96 (2010). The ECJ referred to the Treaties as the "constitutional charter of the EU" in the famous Les Verts case (ECJ Case 294/83 Les Verts v European Parliament [1986] ECR 1339, para 23) and later on referred to the "basic constitutional charter," the "constitutional principles," and "constitutional guarantees" of EU law. See Joined Cases C-402/05 P and C-415/05 P, Yassin Abdullah Kadi and Al Barakaat International Foundation v. Council of the European Union and Commission of the European Communities [2008] ECR I-06351 (Kadi I), paras. 5, 285, 290.
} 
legal regime difficult to amend, generating a "spontaneous internal hierarchy of norms" that was accelerated by "the multiplication of adjudicative authorities." ${ }^{\text {"7 }}$ The recognition of fundamental rights legally and factually aggravated the procedure to amend the general principles of the legal order and a embryonal model of judicial review of legislation pushed the supra-national legal order on the path of constitutional regimes.

The concept of constitutional identity, however, tends to refer to the constitutional identities of the Member States and not to the constitutional identity of the EU. These conceptions make the concept of constitutional identity ambiguous. Moreover, the supranational and national conceptions of constitutional identity seem to be connected to each other. In fact, national recognition and acceptance of the main pillars of the constitutional identity of the EU - the principles of primacy of EU law and direct effect-took time, effort and judicial fine-tuning. The meaning of this move from the point of view of national constitutions was huge and potentially devastating in legal terms. The sole recognition of the principle of primacy of EU law required national courts to accept that $\mathrm{EU}$ law trumps national statues-even if entered into force later in time-and national constitutional law. Nevertheless, the principle was accepted in all Member States, including jurisdictions such as the UK, where the strong adherence to the principle of parliamentary sovereignty emphasized the revolutionary meaning of the acceptance of the principle of primacy of EU law. ${ }^{28}$ Little wonder if many of the Member States did not accept that EU law could set aside constitutional law without reservations. Nonetheless, Member States that resisted an unconditional acceptance of the primacy principle over national constitutional law specified that only under certain circumstances national constitutional law could prevail over EU law.

National constitutional courts, supported by an intense debate in the national constitutional scholarship, developed a rich scenario of doctrines of national constitutional reservations to the principle of primacy of EU law. The constitutional identity discourse moved from this friction between national constitutional courts and the ECJ. The concept of constitutional identity review is commonly linked to the German Constitutional Court's refined case law and in particular to one stream of its "European" case law inaugurated with the famous Lisbon Judgement in 2009. ${ }^{29}$ In this mainstream narrative, the identity review is contrasted to and differentiated from other two other typologies of review related to the application of EU law in the domestic legal order: the fundamental rights protection standard of the

27 Cristoph Möllers, Pouvoir Constituant-Constitution-Constitutionalisation, in PRINCIPLES OF EUROPEAN Constitutional LaW 169, 195 (von Bogdandy \& Bast eds., 2d ed. 2010).

${ }^{28}$ See Kumm, supra note 15, at 263.

29 The notion of constitutional identity already entered the German Federal Constitutional Court case law as early as 1974 in the Solange I decision, then the Federal Constitutional Court interpreted the German basic law's identity as limiting the transfer of powers at European Level in force of the principle of openness. The notion of identity laid on the background for several years, and took center stage again in 2009 in the Lisbon Judgement. 
Solange stream and the ultra vires review of the Maastricht stream. Nonetheless, identity conceptualization existed also before the Lisbon judgment. ${ }^{30}$ In many decisions, both the German Constitutional Court and other national supreme and constitutional courts referred to constitutional limits to the application of EU law in domestic legal systems. These limits were contrasted to the limitations of sovereignty permitted by many "European clauses" of national constitutions and were therefore labelled as "counterlimits" in the legal scholarship. ${ }^{31}$ The latest developments of the identity review in the German case law reveal a process of blending of ultra vires and identity review. ${ }^{32}$ These developments suggest reference to national constitutional identity as to any doctrine setting national constitutional limits to the application of EU law.

\section{Constitutional Identity as Difference versus Constitutional Identity Despite Difference}

Within the framework of this broad understanding of national constitutional identities - not necessarily limited to the identity review outlined by the German Federal Constitutional Court-a further ambiguity emerges. The ambiguity mirrors a duplicity of the concept of constitutional identities within the constitutional orders of the Member States: Identity as difference and identity despite difference. In the first sense, constitutional identity is based on differences distinguishing one constitution from another. "Constitutional identity as difference" privileges specificities and peculiarities of a given constitutional order.

In another sense, constitutional identity serves as a cognitive tool to recognize the identity of a constitution despite all transformations, modifications and amendment that occurred in a given constitutional experience-"constitutional identity despite difference". In this sense, for example, a constitution may remain the "same" as the one originally adopted, despite several amendments and interpretative transformations. Its self may not change, despite all textual and interpretative differences brought by decades or centuries of constitutional experience. Constitutional identity despite difference represents a limit to any

\footnotetext{
${ }^{30}$ Already in Solange I (BVerfG, BVerfGE 37, 271, May 29, 1974), the German Federal Constitutional Court affirmed that Article 24 of GG "does not open the way to amending the basic structure of the Basic Law, which forms the basis of its identity" (Rn. 43). For a contextualization of this decision within the German doctrinal struggle to accept the primacy of EU law, see Bill Davies, Resistance to European Law and Constitutional Identity in Germany: Herbert Kraus and Solange in its Intellectual Context, 21 EUR. L.J. 434-59 (2015).

${ }^{31}$ This expression was firstly used by Paolo Barile. See Paolo Barile, Ancora su diritto comunitario e diritto interno, in 6 STUDI PER IL VENTESIMO ANNIVERSARIO DELL'ASSEMBLEA COSTITUENTE 33-54 (1969).

32 In the $O M T$ saga, the German Federal Constitutional Court outlined a relation between ultra vires and identity review, specifying that the former is a species of the genus of the latter. See BVerfG, Case 2 BvR 2728/13, para. 153, June 21, 2016, https://www.bundesverfassungsgericht.de/SharedDocs/Entscheidungen/EN/2016/06/rs20160621_2bvr272813e n.html. For more on this point, see Mehrdad Payandeh, The OMT Judgment of the German Federal Constitutional Court: Repositioning the Court within the European Constitutional Architecture, 13 EUR. CONST. L. REV. 400, 414 (2017).
} 
source of legal transformation of the constitution, including the constitutional amendment power. In some cases, the content of constitutional identity despite difference is explicitly protected by special provisions of the constitution, commonly known as eternity clauses. ${ }^{33}$ In other cases, even in the absence of any explicit constitutional provision of unamendability, constitutional identity emerges from theories-and judicial doctrines-of implicit unamendability. ${ }^{34}$

Explicitly or implicitly unamendable constitutional cores only spell out those elements that are needed to acknowledge constitutional identity in the latter sense- "Constitutional identity despite difference". In fact, the unamendable core of any constitution essentially sets the limits to its own transformation, both through constitutional amendment or through interpretative shifts. There may be a partial of full overlap in the content of the two concepts of constitutional identity. A peculiar principle of a given constitution may differentiate it from other constitutions. Simultaneously, the same principle may be established as unamendable by the eternity clause-or by means of implicit unamendability doctrines. Elements of constitutional identity as difference may, but not necessarily are, part of constitutional identity despite difference. On the contrary, elements of the former conception of constitutional identity-constitutional identity as difference-cannot overlap. This is true by definition, as this conception of constitutional identity only encompasses elements that distinguish one constitution from another. The Irish Constitution is different from many other constitutions, as only it provides a constitutional protection of the right of the unborn as to one enshrined in Article 40.3.3. Certain elements of this conception of constitutional identity may be shared by other Member States, but not by all of them. A typical example is the republican form of the state, proclaimed as explicitly unamendable in some of the national constitutions of EU Member States, whereas other Member States' constitution design a monarchical form of the state.

Moreover, the unamendable core of different constitutions-constitutional identity despite difference-may largely overlap. Most, if not all Member States' constitutions protect the rule of law, the separation of powers, the principle of democracy, the protection of fundamental rights and other basic principles of the European common constitutional heritage. These principles are "eternally" protected in many national constitutions, either by

\footnotetext{
${ }^{33}$ The term "eternity clause" may be misleading, as constitutional identity itself is a dynamic concept, subject to transformation and reinterpretation. For this relativity of the eternal, see GARY JEFFREY JACOBSOHN, CONSTITUTIONAL IDENTITY 325-26, 363 (2010); ROSENFELD, supra note 21, at 209. For a different account on this point, see the article by Monika Polzin in this special issue, where she affirms that "constitutional identity and the content of eternity clauses should not be equated." Monika Polzin in this volume, 18 GERMAN L.J. (2017). We may agree on this assertion, but we hold eternity clauses-where present in constitutional texts-as fundamental, even if not exclusive, sources of the constitutional identity of a given Constitution.

34 The debate on eternity clauses and unconstitutional constitutional amendments became a classic one in the postwar developments of constitutionalism. For a detailed overview of this debate, and a precious contribution to it, see Yaniv Roznal, Unconstitutional Constitutional AMENDMENTS: The Limits of AMENDMENT PoWers (2017).
} 
explicit provisions of unamendability or by implicit doctrines. Constitutional identities despite difference only consist of fundamental principles and some constitutional oddities may be contingent and changeable elements of a constitution. ${ }^{35}$

\section{Trends-Constitutional Identities: Shields or Swords?}

This Section explores some trends concerning the concept of constitutional identity in the European legal discourse and practice. This Section focuses on the development of two main uses that national constitutional courts have made of the concept of national constitutional identities. According to the first one, the concept has been used as a shield: National constitutional courts aimed at protecting national constitutional identities against legal reform of the EU. On this front, national constitutional courts referred both to distinctive elements of their constitutions - constitutional identity as difference-and to fundamental principles of constitutionalism that are largely shared in the European constitutional tradition-constitutional identities despite difference. On the second front, national constitutional courts have used national constitutional identities as swords. In these cases, national courts did not use constitutional identities as limits to further integration, but as operative clauses needed to solve an existing conflict between EU law and national constitutional law. The notion recalls a terminology used by other scholars in the field of studies on constitutional identity, but is not equivalent to the use that will be done of the shields/swords terminology in this article. ${ }^{36}$

In fact, in Konstadinides' work constitutional identity is interpreted as a shield when the concept is invoked by the ECJ as a legitimate EU law derogation and as a sword when the concept is invoked by national constitutional courts-and, in particular, by the German Federal Constitutional Court-as a break to a transfer of competences to the EU and a tool of judicial review of national implementation measures of secondary legislation. On the contrary, in this Article, the distinction refers to the impact of the use of constitutional identity in regard to legal reform of the EU. In this sense, the use of the shield/sword concept is much closer to the one used by other scholars ${ }^{37}$ to describe the relations between EU law and national constitutional law. In particular, Kumm distinguished between the use of constitutional identity as legitimate institutional civil disobedience on one side, and the use of constitutional identity as institutional conscientious objection on the other. The latter demands to accommodate a legal obligation of a Member State because of a deeply held

\footnotetext{
35 Neil Murphy, Article 4(2) TEU: A Blow to the Supremacy of Union Law, 20 TRINITY C. L. REV. 94,111 (2017).

${ }^{36}$ For the basis for image of constitutional identity used as a shield or a sword, see Konstadinides, supra note 7.

37 See Mattias Kumm, Moral Point of Constitutional Pluralism. Defining the Domain of Legitimate Institutional Civil Disobedience and Conscientious Objection, in PHILOSOPHICAL FOUNDATIONS OF EUROPEAN UNION LAW 216-46 (Julie Dickson \& Pavlos Eleftheriadis eds., 2012); Julio Baquero Cruz, Legal Pluralism and Institutional Disobedience in the Eruopean Union, in CONSTITUTIONAL PLURALISM IN THE EUROPEAN UNION AND BEYOND 249-68 (Matej Avbelj \& Jan Komárek eds., 2012).
} 
and specific constitutional commitment in that given legal order. ${ }^{38}$ On the contrary, the former-legitimate institutional civil disobedience-consists in an act refusing compliance to EU law and bases its refusal on principles that are imagined to be shared by both EU and national law and is therefore directed towards legal reform of European law. The notion of constitutional identity as shield/sword applied in this Article combines parts of the aforementioned notions and tests them in light of the analytical accounts outlined in the first part of the Article.

\section{Constitutional Identities as Shields}

The gradual affirmation of a European constitutional identity, nature, in the above mentioned minimal and descriptive sense was certainly not clear of national constitutional obstructions. Despite or even exactly because of the "constitutional blindness" 39 of the European integration process, the growing impact of EU law over national constitutions generated concern. It comes as no surprise that the gradual affirmation of a constitutional character of the EU triggered an active reaction by national constitutional and supreme courts. Especially after the constitutionalization of the identity-clause, brought by the rephrasing of the Lisbon Treaty, national constitutional courts focused carefully on the meaning of constitutional identity and the protection of it. Even before the Treaty of Lisbon-and even before the Treaty of Maastricht, introducing the identity clause for the first time ever-judgments had already been pronounced on the matter. National constitutional courts reviewed the compatibility of the European integration process sometimes in occasion of the ratification procedure of Treaty amendments and other times in occasion of other constitutional momentums of the European integration process. In these occasions, national constitutional courts have often warned on ultimate limits of the European integration process, employing the concept of constitutional identity as a threat for the future. Although this approach has earned some constitutional courts-and especially the German Federal Constitutional Court-the name of "dog that bark but never bites," ${ }^{40}$ the ultimate purpose of this use of constitutional identity has not always been mere "barking."

Initially, constitutional identities have been taken up as national shields not to stop the European integration process, but to guide it towards a preferred constitutional direction.

\footnotetext{
38 See Kumm, supra note 37, at 237.

39 The "federal blindness" could be considered a species of the genus "constitutional blindness." For the federal blindness, see Hans Peter Ipsen, Als Bundesstaat in der Gemeinschaft, in PROBLEME DES EUROPÄISCHEN RECHTS: FESTSCHRIFT Für WALTER HALLSTEIN ZU SEINEM 65. GeBURTSTAG 248-65 (Ernst Caemmerer, Hans Jürgen von Schlöchauer, \& Ernst Steindorff eds., 1966).

${ }^{40}$ Christoph U. Schmid, All Bark and No Bite: Notes on the Federal Constitutional Court's "Banana Decision", 7 EUR. LAW J. 95-113 (2001); Joseph H. H. Weiler, The "Lisbon Urteil" and the Fast Food Culture, 20 EUR. J. INT'L L. 505, 505 (2009).
} 
This was, at least, the effect of the Solange $I^{41}$ and Frontini ${ }^{42}$ decisions: National constitutional courts raised the shields of constitutional identity not to mark an absolute limit to the transformation of the European communities. On the contrary, constitutional identities contributed to generate the ECJ case law on fundamental rights protection and to shape one of the founding pillars of the European constitutional identity. Constitutional identities have been taken up as "soft shields" not to protect a peculiar constitutional specificity of a given legal order, but to generate a convergence in the constitutionalization of European law. Once the protection of fundamental rights was included in the ECJ jurisprudence, national constitutional courts laid down the shields of constitutional identity.

Differently, constitutional identities have been used as "hard shields" when national constitutional courts claimed ultimate limits of the European integration process. In this respect, the seminal example is the identity review developed by the German Federal Constitutional Court, where it states that some essential state functions may not be transferred at European level. In this case law, the German Federal Constitutional Court raised a hard shield, setting ultimate limits to the European integration process. No treaty amendments might ever assign to the EU those competences that would bear a risk of emptying the substantive content of the principle of democracy in the Member States. Among these competences, the German Federal Constitutional Court listed decisions on substantive and formal criminal law; decisions on the disposition of the monopoly on the use of force by the police within the state and by the military towards the exterior; fundamental fiscal decisions on public revenue and public expenditure, the latter being particularly motivated, inter alia, by social policy considerations; decisions on the shaping of living conditions in a social state; and decisions of particular cultural importance, for example on family law, the school and education system and on dealing with religious communities. ${ }^{43}$

In this case, constitutional identity is taken up as a hard shield, not to promote the development of the European integration process towards a certain direction, but to set ultimate domestic constitutional limits to it. To a certain extent, constitutional identity removes some policy areas from the disposal of the Treaty-amending power of the "masters of the Treaties"-for example, the Member States-and contributes to a "negative" definition of the unamendability margin of EU treaty law.

\footnotetext{
${ }^{41}$ BVerfG, BVerfGE 37, 271, May 29, 1974.

${ }^{42}$ See Corte Cost., 27 dicembre 1973, n. 183, Giur. it. 1973, II, 2401 (It.).

43 See BVerfG, 2 BvE 2/08, para. 252, June 30, 2009, https://www.bundesverfassungsgericht.de/SharedDocs/Entscheidungen/EN/2009/06/es20090630_2bve000208e n.html.
} 


\section{Constitutional Identities as Swords}

National constitutional identity has not only been used to block, hard shield, or guide, soft shield, legal reforms in the EU. In recent times, identity-related arguments played a new crucial role in composing legal conflicts between EU law and national law. This trend emerged very clearly between the end of 2016 and the beginning of 2017. In less than a month, the Hungarian Constitutional Court issued a decision substantially hostile to EU law, ${ }^{44}$ developing a fundamental rights review and an ultra vires review-the latter composed of a sovereignty review and an identity review; the Danish Supreme Court ruled a ECJ decision as ultra vires; ${ }^{45}$ and the Italian Constitutional Court submitted a new reference for preliminary ruling in the so-called Taricco case, alleging a possible violation of Italian constitutional identity. ${ }^{46}$ This exceptionally frequent referral to identity claims in such a short span of time was announced by some early signals emerged, once again, in the German Constitutional Court case law. The Tribunal in Karlsruhe engaged a rough judicial dialogue with the ECJ in the famous OMT saga, submitting its first reference for preliminary ruling in 2014, and finally deciding on the case in June 2016. In the same year, the German Federal Constitutional Court issued an important decision on a European Arrest Warrant case. In its order, ${ }^{47}$ the German Federal Constitutional Court declared that the protection of fundamental rights Court may include review of sovereign acts determined by Union law if this is indispensable to protect the constitutional identity guaranteed by Article 79 section 3 of the Basic Law. In short, the German Federal Constitutional Court relied both on the eternity clause and the European identity clause to perform a German constitutionalidentity oriented interpretation of EU law. ${ }^{48}$

\footnotetext{
44 See Hungarian Constitutional Court, Case 22/2016 (XII. 5.) AB, Nov. 30, 2016, hunconcourt.hu/letoltesek/en_22_2016.pdf.

45 Supreme Court of Denmark, Case 15/2014, Dec. 6, 2016, http://www.supremecourt.dk/supremecourt/nyheder/pressemeddelelser/Pages/TherelationshipbetweenEUlawa ndDanishlawinacaseconcerningasalariedemployee.aspx.

${ }^{46}$ Corte Cost., 26 gennaio 2017, n. 24, Foro it. 2017, II, 394 (It.), translated in Order No. 24 - Year 2017, CORTE COSTITUZIONALE, http://www.cortecostituzionale.it/documenti/download/doc/recent_judgments/O_24_2017.pdf.

47 BVerfG, 2 BvR 2735/14, Dec 2015, https://www.bundesverfassungsgericht.de/SharedDocs/Entscheidungen/EN/2015/12/rs20151215_2bvr273514e n.html. The $O M T$ saga was recently followed by a new reference for preliminary ruling in the so-called Quantiative Easing case, BVerfG, 2 BvR 859/15, Jul 18., 2017, http://www.bundesverfassungsgericht.de/SharedDocs/Entscheidungen/DE/2017/07/rs20170718_2bvr085915.ht $\mathrm{ml}$.

48 The German Federal Constitutional Court interestingly affirmed that the identity review under German constitutional law does not violate EU law. On the contrary, it is in line with the principle of sincere cooperation and inherent in the concept of Article 4(2) TEU. See BVerfG, 2 BvR 2735/14, Rn. § 44).
} 
Early signals of "judicial soft sovereignism," however, also originated elsewhere. Only two years prior, the Italian Constitutional Court declared customary international law on state immunity inapplicable in the Italian legal system as far as war crimes and crimes against humanity are concerning, relying on constitutional-identity related arguments ${ }^{49}$ Although the decision dealt with international and not European law, it relied on the counterlimits conceptual background that was developed in relation to EU law. The very first decision revealing a new approach of national constitutional courts toward the principle of primacy of EU law dates back to 2012, when the Czech constitutional court issued its famous Landtova decision. ${ }^{50}$ With its decision, the Czech Constitutional Court proclaimed a decision of the ECJ ultra vires. Although this decision needs to be contextualized, being tightly connected with an internal dispute between the Constitutional Court and the Supreme Administrative Tribunal, the emphasis that the Constitutional Court put on national history may be interpreted as an early signal of a new trend of claiming national peculiarities before the ECJ. ${ }^{51}$

Although each case is different from the others, they seem to reveal a new practice in the national Constitutional and Supreme Courts' use of constitutional identity. The concept is no longer used as a shield to protect national constitutional identities against further European integration, but as a sword to fend off the authority of EU law over a Member State jurisdiction. This trend may generate concern, especially when Member States take up illiberal concepts of identity. Nonetheless, this trend triggers new legal challenges that are not necessarily linked with the emergence of illiberal constitutionalism in some Member States.

\section{Diverging and Converging Constitutional Identities in European and National Constitutional Law}

The accounts of constitutional identity discussed above are essentially descriptive and analytical categories. This Section combines these categories and explores various combinations of conceptions and uses of constitutional identity, focusing on specific challenges related with each specific sub-category. The Article contends that different conceptions and uses of constitutional identity have a different impact on the European

\footnotetext{
49 Corte Cost., 22 ottobre 2014, Foro it. 2015, I, 1152 (It.), translated in Judgment No. 238 - Year 2014, CORTE COSTITUZIONALE,

http://www.cortecostituzionale.it/documenti/download/doc/recent_judgments/S238_2013_en.pdf.

50 See Czech Constitutional Court, Case PI. ÚS 5/12 Slovak Pensions XVII, Jan. 31, 2012, https://www.usoud.cz/en/decisions/20120131-pl-us-512-slovak-pensions/.

51 The Czech Constitutional Court harshly criticized the ECJ decision, noting that "failure to distinguish the legal relationships arising from the dissolution of a state with a uniform social security system from the legal relationships arising for social security from the free movement of persons in the European Communities, or the European Union, is a failure to respect European history, it is comparing things that are not comparable." Id.
} 
composite constitutional adjudication system and that the institutional and procedural framework should be calibrated accordingly.

A characterizing feature of the identity debate in the EU is the ambiguity affecting the identification of the concept. Against a background of harsh conceptual disagreements, the analytical categories outlined above may facilitate a more comprehensive understanding not only of the many different streams of the constitutional identity discourse, but may also facilitate the identification of the main challenges that the theory and praxis of constitutional identity will face in the future. In fact, the combination of the analytical categories outlined above, reveal sub-categories of the discourse and specific declinations of constitutional identity. First, constitutional identity may refer to the European constitutional identity-for example, the fact that the EU has a constitution.

If interpreted in this sense, a narrower understanding of European constitutional identity may then refer to the characters of the European Constitution distinguishing it from other constitutions - "European constitutional identity as difference"-or to the unamendable characters of the European constitution- "European constitutional identity despite difference". On a different layer, constitutional identity may refer to Member States' constitutional identities. If interpreted in this sense, Member States' constitutional identity may refer to constitutional elements differentiating one national constitution from another-"constitutional identity as difference" - or to the unchangeable constitutional core characterizing a given constitution- "constitutional identity despite difference."

Moreover, elements of constitutional identities despite difference may overlap between constitutional jurisdictions of the Member States, forming a common constitutional heritage that grounds the same identity of the European constitution. In these cases, converging constitutional identities will emerge, whereas in the opposite scenario it will be a matter of diverging constitutional identities. Depending on the preferred understanding of Member States' constitutional identities, challenges and possible justifications arising from different uses of constitutional identity may vary significantly. These challenges and potential justifications are explored below.

\section{European Constitutional Identity as Difference}

The recognition of a European constitutional identity as difference seems one of the most puzzling challenges in the combination of the above outlined analytical categories. Indeed, the concept of identity as difference requires the comparability of a subject with different subjects of the same genus. The legal foundation of the European constitutional order, 
however, assumes the sui generis nature. ${ }^{52}$ Therefore, it seems incompatible with any comparison with national experience of state constitutionalism. Nonetheless, the concept of "European identity" emerges explicitly in the treaties. It is no coincidence if the concept entered the Treaties in 1992. It was, the often overlooked, part of the Maastricht constitutional compromise that both entailed the acknowledgment and respect of national constitutional identities (then Article F TEU) and the recognition of a "European identity" on the international scene (then Article B TEU), ${ }^{53}$ clearly outlined through differentiation with other international subjects. ${ }^{54}$ The uniqueness of the European constitutional identity does not derive from any specific provision of the Treaties. The same fact that the, formally, international European treaties are among the sources of the European constitutional identity reveals the extraordinary difference of the European Constitution and its composite and incomplete character. Moreover, elements of a differential European identity are possible to recognize, especially if contrasted with some constitutional other: Common origins, common values and common destiny emerge clearly from the perspective of a differentiation from the US identity. ${ }^{55}$

\title{
II. European Constitutional Identity Despite Difference
}

The development of the constitutional discourse within the European Communities and European Union did not stop to the issue of the existence of a European constitution. A new horizon recently emerged both in the ECJ case law and in the European legal scholarship:

${ }^{52}$ ECJ, Case 26-62, Van Gend \& Loos, [1963] ECR 1. On the exceptionalism of the European constitutional path, see Joseph H. H. Weiler, In Defence of the Status Quo: Europe's Constitutional Sonderweg, in EUROPEAN CONSTITUTIONALISM BEYOND THE STATE 7-25 (Marlene Wind \& Joseph H.H. Weiler eds., 2003).

${ }^{53}$ Article 2 states that one of the objectives of the $\mathrm{EU}$ is "to assert its identity on the international scene, in particular through the implementation of a Common Foreign and Security Policy, including the progressive framing of the Common Defence Policy." A similar wording was restated in the Preamble of the TEU with the Treaty of Lisbon, stating that

\begin{abstract}
to implement a common foreign and security policy including the progressive framing of a common defence policy, which might lead to a common defence in accordance with the provisions of Article 42, thereby reinforcing the European identity and its independence in order to promote peace, security and progress in Europe and in the world.
\end{abstract}

\footnotetext{
${ }^{54}$ This process of recognition of a European identity through differentiation with other countries and their foreign policy already emerged in the Copenhagen Summit Declaration of December 14, 1973, where the (then) nine foreign ministers referred to the diversity of cultures and to a common heritage, emphasizing the rule of law, representative democracy, social justice and respect for human right as "fundamental elements of European Identity". See Document on the European Identity, Copenhagen Summit Declaration, December 15, 1973. On this document, see Claes, supra note 5 , at 115.

${ }^{55}$ For this perspective, see Armin von Bogdandy, The European Constitution and European Identity: Text and Subtext of the Treaty Establishing a Constitution for Europe, 3 INT'L J. CONST. L. 295-315 (2005).
} 
The recognition of an own constitutional core of the EU. Following the analytical categories outlined above, the issue could be phrased as follows: Once we accept that the EU has a constitution, does the EU have a constitutional identity despite difference? Is there any constitutional core protected from any European, national, international change/amendment/interference? In some authors' view, the content of a constitutional core of the EU is currently "in the making" ${ }^{56}$ and is enshrined in Articles 2 TEU. ${ }^{57}$ The ECJ proclaimed the EU's constitutional core in the seminal Kadi I case by affirming that in virtue of this core "no circumstances permit any challenge to the principles that form part of the very foundations of the Community legal order." ${ }^{\text {"58 }}$ Consequently, the ECJ introduced a provision that allows the EU to set limits to its international obligations, substantially developing a sort of European "counter-limits" doctrine. The EU constitutional core-or identity as difference-should be protected also from interferences and violation possibly having source in EU law or in member states national law. Even though it was objected that Article 2 has no capacity to create autonomous rights, ${ }^{59}$ it was argued that the constitutional core enshrined in Articles 2 TEU is now "translated into enforceable rights through by way of European citizenship"60 and should be protected not only against international threats but also against European and national interferences. In case of violation of the constitutional core of the EU by means of acts of the Member States, the treaty also provides a political remedy in Article 7 TEU. Other authors expanded this line of reasoning and imagined a "Reverse Solange" 61 test, claiming that in cases of serious and persistent breaches of EU law, a judicially enforceable action based on EU law should be available.

\footnotetext{
${ }^{56}$ Daniel Sarmiento, The EU's constitutional core, in NATIONAL CONSTITUTIONAL IDENTITY AND EUROPEAN INTEGRATION 177, 187 (Alejandro Saiz Arnaiz \& Carina Alcoberro Llivinia eds., 2013). According to the same author, the EU's constitutional core is founded on "three normative ideals" that "can be expressed under the generic categories of Democracy, Rights and Solidarity." Id. at 180.

${ }^{57}$ Article 2 states that "the Union is founded on the values of respect for human dignity, freedom, democracy, equality, the rule of law and respect for human rights, including the rights of persons belonging to minorities. These values are common to the Member States in a society in which pluralism, non-discrimination, tolerance, justice, solidarity and equality between women and men prevail."

58 Case C-402/05 P and C-415/05, P. Kadi and Al Barakaat International Foundation v. Council and Commission [2008] ECR I-6351.

${ }^{59}$ Referring to the principles enshrined in the (then) Article 2 EEC, the Court held that this Article "cannot impose legal obligations on Member States or confer rights on individuals": Case 126/86, Giménez Zaera [1987] ECR 03697, at 11

${ }^{60}$ Sarmiento, supra note 54 at 184.

${ }^{61}$ Armin Von Bogdandy et al., Reverse Solange-Protecting the Essence of Fundamental Rights Against EU Member States, 49 COMMON MKT. L. Rev. 489-519 (2012).
} 


\section{Diverging National Constitutional Identities - National Constitutional Identities as Difference}

If national constitutional identity refers to constitutional elements differentiating one constitution from another, challenges may emerge when EU law is not in line with specific provisions of a Member State's Constitution. The impact of EU law on national legal orders made the scenario of a conflict between EU law and national constitutional law increasingly likely, and related challenges are far from purely theoretical. In these cases, conflicts between EU law and differential elements of national constitutional identities should be treated carefully when those elements are also part of the Member State' constitutional identity as difference. Whereas EU law usually trumps national constitutional law, ${ }^{62}$ in these cases, the obligation to respect national constitutional identities may take center stage. The role played by the commitment to respect national constitutional identities, however, plays a different role depending on the circumstances. It may be worth recalling that not every constitutional provision contributes to build the identity of the constitution. A constitutional provision may be specific of a given constitutional order, clear and specific, and still not essential to define the unamendable constitutional identity of a Member Stateconstitutional identity despite difference. A clear example is offered by the constitutional provision of the German basic law that provided a general prohibition for women from serving in the armed forces. This constitutional provision conflicted with the EU principle of non-discrimination ${ }^{63}$ and was therefore modified by a constitutional amendment. This amendment solved the conflict between EU law and a national constitutional peculiarity by removing the national constitutional peculiarity via constitutional amendment. The Federal Constitutional Court would have probably solved such a case by setting aside German constitutional law and applying EU law instead, as the legislative history of this constitutional provision "is thin, the principle it embodies is unclear, and it has not played any significant role whatsoever in German public and political life."64

On the contrary, a seminal example of an essential element of constitutional identity defined through a specific constitutional provision differentiated from other constitutions is the Irish constitutional commitment to the protection of the right of the unborn. The provision reflects a characteristic and essential profile of the Irish Constitution, mirroring Irish

\footnotetext{
62 On the primacy of EU law in relation to national constitutional law, see ECJ, Case 11/70, Internationale Handelsgesellschaft, [1970] CR 1125, para. 3; ECJ, Case 106/77, Simmenthal, [1978] ECR 629, paras. 21 et seq.; ECJ, Case 149/79, Xommission v. Belgium, [1980] ECR 3881, para. 19; ECJ, Joined Cases C-46 \& 48/93, Brasserie du Pêcheur and Factorartame II, [1996] ECR I-1029, para. 33; ECJ, Case C-473/93, Commission v. Luxemburg, [1996] ECR I-3207, paras. 37 et seq.; ECJ, Joined Cases C-10/22/97, IN.CO.GE.'90 et al., [1998] ECR I-6307, paras. 11, 20 et seq.; ECJ, Case C-285/98, Tanja Kreil, [2000] ECR I-95, paras. 25 et seq.; ECJ, Case C-213/07, Michaniki, [2008] ECR I-9999, paras. 62 et seq.

${ }^{63}$ See ECJ, Case C-285/98 Tanja Kreil v. Bundesrepublik Deutschland [2000] ECR I-69.

${ }^{64}$ Kumm, supra note 15 , at 297.
} 
constitutional identity in one of its deepest national and historical roots. Therefore, it is extremely unlikely that Irish Courts would ever set this provision aside in favor of EU law. Moreover, it is no coincidence if the Irish constitutional provision was, and still is, textually mentioned by a specific protocol to the EU Treaties. ${ }^{65}$

The national case law on constitutional identity may have the purpose of emphasizing important differential elements of a given constitutional tradition, so to warn the European Constitutional Amendment Power-the Member States in their capacity of masters of the Treaties. In this sense, national constitutional identities-understood both as differential and unamendable elements of a constitution-are used as shields to prevent further European integration that implies obligations in contrast with the elements differentiating a specific national constitutional oddity. It does not necessary follow that further integration is impeded by differentiated national constitutional identities. In these cases, differentiated integration may succeed in accommodating both the will of certain Member States to proceed further on the integration path, and the concerns of other Member States to protect their constitutional identities. Differentiated integration can serve-and has already been employed-as an efficient instrument of preventive neutralization of ultimate conflicts between EU law and diverging elements of national constitutional identities. ${ }^{66}$

Unfortunately, reducing the accommodation of diverging elements of constitutional identity to the differentiated integration experience would amount to a simplistic and naif approach. Legal conflicts often emerge only in the phase of application-and prior interpretation-of law and are therefore not easily predictable. The possibility of a conflict between EU law and national constitutional identities has been considered a merely theoretical issue for a long time. The extension of EU competence over time has recently increased the chances of such a concrete conflict, ${ }^{67}$ and with all likelihood further conflicts will continue to emerge. In these cases, the understanding of national constitutional identities as swords may facilitate the management of identity-related conflicts that have not been neutralized through differentiated integration. Such a use of the identity-clause should not necessarily be perceived as a disintegrative force in the EU. It certainly raises new challenges. While from the theoretical point of view, it was possible to note that in cases of constitutional identity-

\footnotetext{
65 Protocol No. 17 (the "Grogan Protocol") of the Maastricht treaty provided that "nothing in the TEU, or in the Treaties establishing the European Communities, or in the Treaties or Acts modifying or supplementing those Treaties, shall affect the application in Ireland of Article 40.3.3. of the Constitution of Ireland." The Protocol was reaffirmed in successive treaty amendments, and is still in force, after being object of reassurances in "the Guarantees" drafted after the Irish "No" in the referendum on ratification of the Lisbon Treaty.

${ }^{66}$ For an analysis of the use of differentiated integration as a means of accommodation of constitutional identityrelated conflicts in the EU, see Pietro Faraguna, Taking Constitutional Identities Away from the Courts, 41 BROOKLYN J. INT'L L. 492 (2016), http://brooklynworks.brooklaw.edu/bjil/vol41/iss2/2.

${ }^{67}$ Leonard F. M. Besselink, National and Constitutional Identity Before and After Lisbon, 6 UTRECHT L. REV. 36, 44 (2010).
} 
related conflicts, "each court is correct according to its own legal order." ${ }^{\text {"68 }}$ When a concrete conflict is at stake, a mere acknowledgment of the theoretical conflict within a pluralist constitutional framework may no longer be considered a satisfactory solution. ${ }^{69}$ What about if national constitutional courts and the ECJ disagree on an identity-related conflict? In these cases, the identity clause should be read differently if the element of constitutional identity at stake is part of a differential national constitutional identity or, in the contrary, belongs to the common constitutional traditions of the Member States.

In both cases, Article 4(2) TEU should be read in conjunction with the principle of sincere cooperation enshrined in Article 4(3) TEU. The two provisions design the sketch of a still blurred institutional and procedural framework in which domestic constitutional courts and the ECJ are called to cooperate closely within a composite system of constitutional adjudication. ${ }^{70}$ Within this framework, national players should be given a prominent role in interpreting the content of constitutional principles characterizing the "constitutional identity as difference" of a Member State. In these cases, the ECJ should rely on national interpretations of differential elements of constitutional identity, as national players are placed in the most appropriate position to ascertain the Member State's "constitutional identity as difference." In these cases, the identity-clause of Article 4(2) TEU does not offer any tool to interpret the national constitutional identity, but refers to constitutional law of each Member State to ascertain the principles that the EU is committed to respect. Given the fact that there may be disagreements among national constitutional players on the interpretation of a national constitutional identity, ${ }^{71}$ the question arises who should the ECJ consider as the "authentic interpreter" of a Member State constitution? Even though there may be no one right answer to this question from a theoretical point of view, ${ }^{72}$ as different constitutional traditions may recognize a crucial role to the Parliament-this seems to be

\footnotetext{
${ }^{68}$ Gareth Davies, Constitutional Disagreement in Europe and the Search for Pluralism 5 (Eric Stein Working Paper No $1 / 2010,2010)$.

${ }^{69}$ For an account in this sense, see Zdenek Kühn, Ultra Vires Review and the Demise of Constitutional Pluralism: The Czecho-Slovak Pension Saga, and the Dangers of State Courts' Defiance of EU Law, 23 MAASTRICHT J. EUR. COMPETITION L. 185-194 (2016).

${ }^{70}$ See von Bogdandy \& Schill, supra note 7, at 1419.

${ }^{71}$ The abovementioned Slovak Pension saga represents a clear example of disagreement on the scope and content of the Czech constitutional identity.

72 The struggle over interpretative authority of the constitutional identity depends on the constitutional tradition of the country and may not necessarily be settled within the internal constitutional order itself. As a matter of principle, helpful indications may derive from the authority of reviewing unconstitutional constitutional amendments. Should the judiciary have such a power, then it is reasonable to accord to the judiciary a prominent role in interpreting the State's constitutional identity. On the contrary, where unconstitutional constitutional amendments are not reviewed by the judiciary, the interpretation of the member state constitutional identity should rely on different sources - political statements, parliamentary resolutions.
} 
the case of France-or to the Constitutional Court, as seems to be the case of Germany, ${ }^{73}$ a pragmatic observation may be helpful on this point. In fact, the only national voice structurally hosted before the ECJ proceedings is the one of Member States' governments. This may amount to the paradox of giving national governments, and thus the expression of a contingent political majority, the duty of being the only national interpreters of national constitutional identity. ${ }^{74}$ The quintessence of the countermajoritarian spirit of constitutionalism-constitutional identity-would be left in the hands of the political majority. This paradox is clearly unacceptable from a constitutional viewpoint. ${ }^{75}$ This is probably why increasingly constitutional courts have decided to drop any reluctance in engaging directly the ECJ and promoted references for preliminary rulings directly to the ECJ. ${ }^{76}$ In some cases-as OMT, Quantitative Easing and Taricco-the references for preliminary ruling were submitted with an explicit intention of emphasizing the importance of the issue at stake in terms of constitutional identity.

\section{Converging National Constitutional Identities-National Constitutional Identities Despite Difference}

The overwhelming majority of cases where constitutional identity is at stake do not involve specific characters of a single Member State constitutional tradition. On the contrary, constitutional identity is often called into question in connection with fundamental principles-such as the rule of law, the separation of powers, the democratic principle, etc. - that are deeply rooted in the European mainstream tradition of constitutionalism. In fact, "constitutional texts in our different policies, especially when it comes to human rights, are remarkably similar." ${ }^{\prime 77}$ Respect for shared elements of constitutional identities is a converging interest of the EU and of the Member States and is not limited to the protection of human rights. The overlap in the content of national constitutional identities is large: Unamendable provisions usually referrer to basic principles of constitutionalism, such as the rule of law, the protection of fundamental rights, the democratic principle, the separation of powers that are unanimously shared by Member States constitutional traditions and by

\footnotetext{
73 For an overview of both constitutional system accepting and rejecting judicial review of constitutional amendments, see Gábor Halmai, Unconstitutional Constitutional Amendments: Constitutional Courts as Guardians of the Constitution?, 19 CONSTELLATIONS 182-203 (2012).

${ }^{74}$ von Bogdandy and Schill, supra note 7.

${ }^{75}$ However, similar objections may be raised to judicial interpretation of constitutional identities, as in these cases "defending the constitutional identity of the state and its core values turns out in many cases to a defence of some hermeneutic foible adopted by five judges against four." See Weiler, supra note, 52 at 17.
}

76 See Marta Cartabia, Europe and Rights: Taking Dialogue Seriously, 5 European Constitutional Law Review, 5-31 (2009) and Marco Dani, National Constitutional Courts in Supranational Litigation: A Contextual Analysis, 23 European Law Journal 189-212 (2017).

77 Id. at 17 . 
the EU itself. Constitutional identities as shields often consist of the basic principles of constitutionalism. This was the case in the first phase of development of constitutional identity doctrines aiming at guaranteeing national standard of protection of fundamental rights (Solange). As well known, the response of the ECJ was the Europeanization of national claims concerning the protection of fundamental rights. ${ }^{78}$

National constitutional courts took up the identity shield with the result of guiding the European integration process in a new context of a EU as a fundamental rights organization. The affirmed need of protection of fundamental rights, as largely shared element of the unamendable core of national constitutions, triggered a transformation of the EU that may nowadays be considered appeased in its general direction. Undoubtedly, disagreements and negotiations over the content of fundamental rights and balancing in concrete still exist between the ECJ and constitutional courts. However, it is not a structural and systematic disagreement, but a pragmatic one that is usually managed by the interaction between the $\mathrm{ECJ}$ and ordinary courts, with some exceptional intervention of national constitutional courts in the so-called judicial dialogue. Furthermore, this process is not irreversible and the emergence of illiberal claims under the mask of national identity is increasingly common. Nevertheless, the deviation from the basic principle of constitutionalism raises specific problems that are not object of this article, as illiberal identities may not be considered "constitutional identities." In fact, the Treaties should be read as a whole and Article 4(2) TEU should be read in light of Articles 2 and 6 TEU. Constitutional identities of the Member States are to be respected only as long as they are compatible with the founding values of the Union and the commitment to guarantee fundamental rights.

Nevertheless, in the area of constitutional liberal tradition, at least at a high level of abstraction, a substantial agreement seems to emerge when a bundle of constitutional principles-separation of powers, adherence to the rule of law, guarantee of fundamental rights-are considered. The material content of national constitutional identities largely converges in these cases. What the German Federal Constitutional Court recognizes as constitutional identity, namely the inviolable core principles protected by the Ewigkeitklausel, consists precisely of the same principles that Article 2 TEU proclaims as the foundational principles of the EU. In a certain sense, the European Treaties constitutionalized a large part of national constitutional identities, following a similar path to the one that led to the supranalization of the protection of fundamental rights after the Solange resistance of the German Federal Constitutional Court. ${ }^{79}$ Nonetheless, once one focuses on concrete constitutional questions connected with the application of these principle, disagreements emerge again. In these case, the so-called judicial dialogue is not only useful, but also necessary. Disagreements emerge only with the interpretation and application of constitutional provisions and therefore may not be settled ex ante through a

78 See Claes, supra note 5, at 135.

${ }^{79}$ See id. at 125. 
careful political negotiation. When constitutional identities converge, at least at a high level of abstraction, the judicial dialogue between national and supranational actors should not accord a prominent interpretative role to national interpreters as in the case of clashes with diverging constitutional identities.

\section{E. Conclusion}

Constitutional identity is an indeterminate concept. Indeterminacy is often a crucial added value for constitutional concepts, as it allows for an adaptation through the time. In addition, constitutional identity has been developed mainly as a judicial multi-faceted tool. It has been used as a tool for self-empowerment of national constitutional courts. This process of selfempowerment has its side-effects: It triggers a process of juridification of the European constitutional space and thus limits politicization. Moreover, the juridification of constitutional identity may hide the opportunistic protection of national interests beyond the noble scope of protecting national constitutional identity. Per sé, constitutional identity is an extremely dangerous tool, not fully compatible with basic principles of constitutionalism. Constitutional identity-related values are difficult to balance-as their weight is supposed to be much greater than the one of other constitutional values. Identityrelated arguments often fail to be subject rational discourses. Therefore, from a normative perspective, the recognition and acceptance of constitutional identity in European constitutional law should be safeguarded with appropriate tools. European constitutional identity may be one of these tools. 